\title{
NEGOTIATING HERITAGE IN DANISH PUBLIC HOUSING RENOVATION
}

\author{
SIDSE M. GUDMAND-HØYER ${ }^{1,2}$ \\ ${ }^{1}$ Territories, Architecture and Transformation, Aarhus School of Architecture, Denmark \\ ${ }^{2}$ Faculty of Architecture, Delft University of Technology, Netherlands
}

\begin{abstract}
This paper presents a significant problem when it comes to the challenging task of safeguarding recentpast architectural heritage with reference to the democratization ideals propagated by the New Heritage paradigm. Based on controversy mapping relating to the renovation of a Danish 1950s high-rise complex of public housing, it discusses how implementing an expanded idea of heritage as what is regarded relevant for and by a given contemporary population of democratic deliberation presents difficulties in ongoing efforts of safeguarding architectural heritage in practice. Thus, the paper raises questions about how heritage understandings are currently negotiated in a complicated process of interdependent partners promoting different agendas; on what terms this negotiation is made, how and by whom. And not least, it discusses the importance of when the issue of architectural quality and the performance of interventions conveying heritage understandings can be addressed and given a binding form for this process and its partners.

Keywords: architectural heritage, public housing, controversy mapping, renovation, new heritage, heritage negotiation, heritage performance, assessment.
\end{abstract}

\section{INTRODUCTION}

This paper discusses a gap between heritage management, preservation practice and recent heritage theory, with an offset in the renovation- and "Future-proofing" interventions initiated by the Danish public housing sector. So far, scholars have paid little attention to how ambitions to preserve built heritage are negotiated between project partners, despite the particular preservation field of built heritage and monuments in architecture education, practice, and theory. Preservation of built heritage is an established field, albeit ever challenged by the fact that preservation as a concept seems to be inseparable from change. For this reason alone, research is required into strategies on how we find common ground when it comes to interpreting, understanding and not least how to convey the issues of heritage valued in practice. However, also the ever broadening sense of what is or could be considered heritage promotes the need to critically investigate how the processes of negotiating and reaching a mutual understanding of these questions can be qualified.

When heritage, can be regarded as whatever traces of the past that speaks to present-day cultural, political and social needs rather than an innate quality [1], [2], the question of who it is that can influence this kind of resonance process immediately becomes essential. A heritage narrative is never comprehensive, and an authenticated narrative is always the narrative of someone [3], [4]. The question of hierarchies and the right to make claims become even more pressing when heritage preservation is seen through the lens of the paradigm New Heritage. According to Fairclough [5], New Heritage promotes heritage as a democratic process of continually assessing what we can use from the past to handle the constant change of identities, places, objects, and traditions. Such broad understanding of heritage as a process [6], of heritage as valuation and of heritage as directing future solutions call for research into how to agree on such processes. Both in general and across cultural differences be it professional, national or social, as this beckons the question whether or not 
objective value assessments can be made in this context - and if so, are some architectural interventions objectively performing better or more qualified than others?

This paper seeks to unfold how built heritage is handled in ongoing renovation practice particular to the Danish public housing sector. Such critical investigation of how theory and practice correspond is needed to qualify the idea of heritage as a generative force in constructing common futures [7]. Just as importantly, it is necessary to create the potential conditions to reach common understandings.

Conditions central to discuss heritage understandings and conveying in general, and specifically in the context of the Danish public housing sector, which still plays a significant role nationally both socially, politically and physically. The altering of existing public housing architecture is ongoing at a grand physical and economic scale to upkeep functionality, affecting both existing social and urban patterns. There is an estimated renovation need of approximately 22.8 million Euros to update the current public housing estates [8]. At the same time, many of the buildings in need of renovation are at present perceived and described by heritage experts and professionals as an integrated part of the history of the development of the Danish Welfare State and thus worthy of preservation [9]-[13]. The 543,324 households in the public housing sector are still highly relevant as integrated part of the Danish welfare system, housing approximately $17 \%$ of the Danish population [14]. None of the 7700 housing estates originally built as public housing are listed as national monuments, while the number of properties classified as worthy of preservation at a municipal level is unknown. However, there is an increasing expectation from heritage experts, from the state, the municipalities as well as from The National Building Fund (NBF), that the heritage related to these buildings should be considered and somehow safeguarded whilst updating and renovating the buildings to meet current requirements [15], [16]. To upkeep a well-functioning public housing sector, the competent project decision-making partners must come to terms and reach temporary understandings or as described by Sehested with reference to Patsy Healy [17] temporary restings. In this context, the term temporary resting means a temporary stabilization of relations and activities that satisfy the different agendas and investment horizons of the project partners. Furthermore, an extensive network of workgroups, external stakeholders and advisors is added to the equation.

This paper argues that the regulatory framework and the complex project networks consisting of multiple interdependent actors challenge the heritage consideration and assessment. Although several competent decision-making partners present within these projects should enable a higher degree of democratization of the heritage understanding and handling, this paper claims that the tools and strategies for weighing proclaimed heritage issues contra required functional optimizations are lacking within this context. The results of current projects in the public housing sector mirror this by the variety of heritage performing architectural solutions conceived to carry the valued narratives of the existing heritage into the future. The renovation of the housing association Søndermarken's 1950's high rises, will be used as a primary case in this paper. The case analysis indicates how the authorized heritage practice and discourse, traditionally valuing tangible heritage's symbolic and intrinsic value [18]-[20] seems to be thoroughly tested when dealing with non-listed, and still functioning buildings classified preservation-worthy. The case studied shows that despite being tested the authorized heritage practice is still dominating the negotiation process, regardless that the heritage consideration is not the common offset of negotiation. This calls for critical reflection from the public housing sector and the renovation project networks. Equally important, it calls for research on which tools and strategies to qualify the ongoing heritage conveying of the built recent past heritage to qualify it as a progressive common understanding driving change - and not merely an added value which can be 
appreciated or not. The conclusion of the paper is twofold. Firstly, if heritage is to become the common ground for future interventions of both experts, non-experts, users, stakeholders, managers and politicians, then we need to develop strategies to reach such common ground. Secondly, if we succeed to qualify the processes of negotiating heritage interpretations and understandings - we will also be able to objectively assess the performance of our interventions intended to convey this understanding.

\section{THEORY}

Heritage is a process of valuation, an assessment intrinsically linked to the prevailing perceptions of history, aesthetics, politics, social models and agendas [21], [22]. The ideals represented by the New Heritage paradigm not only democratizes this valuation but also links heritage processes to shaping the future rather than to safeguarding traces of the past [23]-[25]. This widening conception of heritage links to forfeiting the classical divide between nature and culture, a collapse also described within the field of Science and Technology Studies (STS). The expanded heritage concept leaves unanswered questions of how to convey such heritage much more open to negotiation, as well of how the related democratization of heritage is probable in practice.

If accepting the New Heritage paradigm, the process of coming to terms on how to understand and interpret built heritage and not least convey it through new interventions becomes crucial. Even more so, a clear critical analysis and further knowledge of such negotiation processes are essential as heritage is an essentially contested concept, according to Bech-Nielsen with reference to Walter Bryce Gallie, and as such is open to varying claims, interpretations and valuations and the content therefore constantly changing [26].

\subsection{Controversy mapping}

The authorized and heritage expert-sanctioned descriptions of how built heritage should be assessed and up kept in Denmark still promotes the inherent value attributed to the original material plan and composition, and the value of the buildings as historical and scientific documents contributing to a national narrative [27], [28]. This agenda is supported by national law when it comes to listed buildings [29] but it is harder to endorse when related to municipal SAVE-registered preservation-worthy buildings and environments. The expert claims towards heritage understanding and the appropriate management, conveying and preservation as described in regulations, guidelines, agendas, and projects, can always be disputed, as heritage represents an essentially contested concept [30]. Disputed not only by non-experts but also from within expert circles, which the history of preservation has shown in many cases. However, asserting claims and sticking to them is also challenged by the organizational, political, planning and project reality of large architecture projects. To explore how the crucial questions of how it is currently decided in practice which heritage narrative should be considered in particular cases and how it is agreed upon which architectural interventions best convey this understanding, the method of controversy mapping, inspired by Yaneva [31], proves useful.

Yaneva has mapped the interrelation of rising controversies within complex project networks to emphasize architecture as a socio-technical discipline. As such, project outcomes cannot be distilled into simple cause-effect decisions or judgments, nor can the results merely be ascribed to the vision or agenda of an architect and client, since external actors are an influential factor. This accommodation of architects' visions in respect to external factors is not a new research subject, and various projects such as cross-cultural exchange research and cross-sectoral corporation research have investigated and detangled such relations. Yet, the 
specific method deployed by Yaneva is developed as part of the project MACOSPOL (Mapping Controversies on Science for Politics), aiming to devise a collaborative platform to map out scientific and technical controversies by developing web-based tools to chart the complex relations between controversies and their dependencies exemplified through cases within different research disciplines. Yaneva's project is an attempt to depict the intertwined and irrepressible project reality of architecture development. In this perspective, architecture projects evolve as reactions to multiple controversies within and around the projects, controversies meaning open-ended questions or issues [32]. Power relations are crucial within complex project networks, like the ones particular to the Danish public housing renovation projects. Notably, when it comes to heritage consideration in such complex networks, the claim or the right to make heritage assessments and valuation is essential as the initial valuations, description, and statements of intent, usually proves normative throughout the project development for what is regarded as existing qualities and thereby what is not [33], [34]. A process which, seen from the perspective of New Heritage, ought to be democratized rather than left to expert assessment.

To disempower the validity of expert assessment leaves the question of how then to state anything about the quality of the architectural interventions' performance, produced to convey heritage narratives in practice as well as the quality of these narratives. Questions related to how we possibly can make objective value assessments, notwithstanding the lack of agreement philosophically on what quality and value exactly are or even on how we should question these concepts.

\subsection{The possibility of objective assessment}

Hans Fink argues that a common value-conception (almen værdiforståelse) can be reached successfully albeit; and as such an objective assessment of subjective projections of value is possible, but only if we are distinct and precise in defining what we are indeed talking about in order to establish whether or not it is successful. In turn, the establishment of whether a process is then successful can be the anchor point of objective assessments. This precision on what we are talking about, what performative ability we are aiming to create, is necessary as value primarily is a comparative ability, an evaluation always being a comparison of something in relation to something else, and as such quality is hierarchical [35]. Moreover, value is primarily a performative quality, the act of being good at something like of writing or of reminding us of how they made windows in the past. Fink also argues that even though it is hard to distinguish between the interrelated processes of something being well done from something being a nice experience, it is possible to do so through description and by being aware that quality is not quality in itself but a quality in relation to a certain process.

\section{MAPPING HERITAGE UNDERSTANDINGS}

This paper is based on the in-depth case study Søndermarken, exploring how consideration for heritage issues pertaining to the estate was established, conceived and, finally, how it is conveyed in the new architectural interventions. The research data consists of project documents such as referendums, project descriptions, internal notes, emails, drawings, applications, and evaluations. These data have been supplemented with interviews with the principal project partners, observations, site visits and document analysis of main documents such as the official regulations and strategies from the municipality and NBF. Inspired by Yaneva's controversy mapping method, the scope has been to extract information from the data to identify the negotiations related to heritage issues throughout the project development process. However, this specific search of why and how heritage considerations have evolved 
by analyzing project related data differs significantly from Yaneva's approach, which is based on public or publicized discourse affecting a project's development in general. The application of this explicit heritage perspective, while following the controversies related to the project development and process in Søndermarken, reveals how the heritage understanding and management was formed by the multiple actors, regulations, laws and the processes of the project. The development began with an initial master plan and NBF pre-application in 2007, later an architect competition was held, the building permit application was developed, and most currently the technical design of the construction documents are completed. The controversy mapping is correlated to the official application and project development processes and regulations described by NBF and the municipality to qualify the findings as comparable with similar cases. The analyses of documents, describing the broader context defining factors of the controversy negotiations, such as the municipal neighborhood development strategies, current public housing sector politics, and aims, as well as the general political agendas of the particular municipality involved, are supplemented by the interviews with project partners. The interviews have been necessary to understand the background and reasons for the controversies further in light of the fact that the most delicate reasons underlying conflicts in relation to controversies and negotiations often are not documented in referendums. Finally, the findings were related to the current authorized and stately sanctioned heritage discourse and practice described by official documents and practitioners. Also, publicized books, reports and guides made by heritage experts on public housing heritage were used to investigate coherence or reinterpretations between these and the heritage performance of the future Søndermarken.

\subsection{Framework: interdependent project partners}

The importance of NBF in the Danish public housing sector cannot be overstated. NBF was established in 1967 by law to promote the sector's self-financing. All housing associations make monthly payments to NBF, which amongst other services, redistribute money through different subsidy systems - one of them being financial support for renovation projects. For the housing associations to be eligible for renovation funding, the projects must meet the regulations and requirements and preferably comply with what has been termed "futureproofing" by NBF. In short, future-proofing in this context means upgrading and altering the architecture and outdoor areas to ensure a diverse tenant profile and avoid empty leases by providing quality, well-functioning, well-kept, healthy and affordable housing [36]. This often includes upgrading of common facilities and outdoor areas, changing apartment layouts and sizes, establishing elevators and mechanical ventilation and often to improve insulation. Project contents, economy and architectural solutions of Danish public housing renovation projects, receiving funding from NBF, is agreed upon between three interdepend, competent decision-making partners: the housing association and its tenant democracy, the municipality, and NBF.

Just as NBF, the tenants must approve of the projects for them to be realized, and likewise the municipality must guarantee for project loans and issue the building permit. Thus, the municipality is, besides being the public housing supervision authority, also legally able to make demands according to building regulations, and local urban or environmental strategies. Additionally, the municipality can make claims towards preservation and aesthetics, if such municipal guidelines and regulations exist. 


\section{SØNDERMARKEN}

Søndermarken was built by Frederiksberg Forenede Boligselskaber in 1950-1955. It was designed by Dominia A/S and was one of the first attempts to industrialize high-rise housing construction in Denmark. It consists of five, 14 storey twin blocks, each sharing a staircase and elevator building. The buildings were constructed of concrete slabs, partly pre-fab, partly cast on site. The façade slabs are mounted with concrete tiles in white and gray. Originally the buildings had open, recessed balconies in connection to the living room windows creating a bay window effect. The parapets are of cast concrete with integrated, extruded concrete flower bowls. The construction is challenged by cold bridges and hardly any insulation. The balcony construction also proved leaky; the balconies were covered with glass in the mid-1990s, and the living room windows were also renewed at the time (Fig. 1).

In summary, the concerns of the current renovation are insulation of the existing façade, upon which a new façade system and cladding will be constructed, in addition to new windows, the establishment of mechanical ventilation, refurbishment and insulation of public staircases, updating common indoor and outdoor areas, new water piping, sewer- and garbage systems. The controversies in the case are many. For this paper, just one is chosen in order to showcase the difficulties related to heritage conveying in the particular project but also in the Danish public housing sector in general.

\subsection{The Balcony Controversy}

The Balcony Controversy is, of course, related to the overall façade design. Initially, however, the central argument was whether or not the balconies should be reopened or not, or if they should even be there at all. In short, the tenants' representation wanted the balconies to be integrated fully into the living room, or at least closed off but unheated, like today, leaving the tenants with an individual option to decide if the balcony should be integrated into the living area entirely. NBF wanted to reopen the balconies as first built since their regulations define balconies as added value to living and housing quality. The municipality wanted to ensure a representation of the effect that the original recessed balconies had in the composition of the façades prior to their covering in the mid-1990s. They saw the former shadow effects of the original balconies as an aesthetic quality the tall façades.

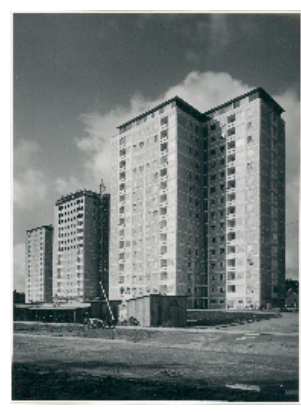

(a)

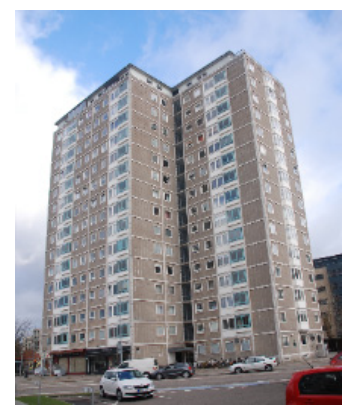

(b)

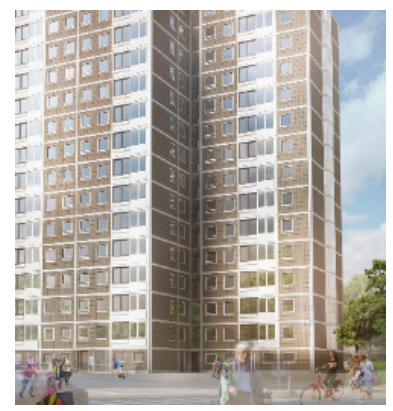

(c)

Figure 1: Partial view of Søndermarken. (a) Photo of Søndermarken when built, from Frederiksberg Stadsarkiv; (b) Photo of Søndermarken today; (c) Rendering of future façade by JJW Architects. 
The controversy settled with the balconies being covered by new window frames slightly recessed from the façade plane. At this point in the project development, the individual tenant is given the option to pay themselves for integrating the unheated balcony with the living room area. Yet, such an option is somewhat challenged by the existing construction of the buildings, which makes it technically difficult to make such individual choices in relation to insulation, fire, and noise, without it being exceedingly costly. Therefore, the result of the construction bidding will prove crucial, since the NBF will not financially support the costs of integrating the balcony and living room since it is not in line with the Future-Proofing aim and regulations. Notably, though, the tenants' demand of covering the balconies with glass has been met.

Though, valuing the compositional qualities of the open balconies in the original façades, the municipality did not insist on reopening the balconies. This is so, despite the fact that the municipality holds a quite rare declaration certified when the buildings were completed in the mid-1950s, which states that they have the legal right to make whatever demands they see fit to all projects relating to changing the appearance of Søndermarken. A quite unusual declaration that testifies to how ground-breaking these buildings were perceived to be at the time of completion. With this declaration in hand, the municipality could easily have enforced a claim to reopen the balconies. But when the permit was given 20 years ago to cover up the balconies, as they are today, heritage concerns were not mentioned in the effort to stop water from entering through the balcony/bay window construction.

The municipal decision not to demand a reopening of the balconies even though appreciating the aesthetic and compositional qualities such an intervention would enhance in Søndermarken must also be seen in the wider controversy and political context. Before the balcony decision settled, the municipality engaged in an effort of urban renewal of the near surrounding neighborhood of Søndermarken, which is to some degree challenged socially, functionally and in regards to infrastructure. Landing the urban neighborhood renewal project with the residents has been challenging for the municipality [37]. The project was opposed by the tenants of Søndermarken since the municipality claimed their right to designate a part of Søndermarken's open green area for the use of a new construction site for an elderly home. Additionally, a new public bicycle path is planned through the grounds as part of the urban renewal strategy for the neighborhood. Thus Søndermarkens green open area is made smaller and easier accessible for the public. As of now, the municipality approved new covering of the balconies in the current renovation project, and thus the NBF decided to give in as well. As already stated, NBF declined to fund work related to integrating the balconies in the living area. Making ends meet in the balcony controversy has taken years as has the development of the overall façade design and construction. A mock-up was built, and multiple meetings between the project advisor team and the municipality have been held to reach a mutual understanding of how the presently perceived qualities and heritage narratives of the existing façades can be conveyed in the new ones.

\subsection{Conveying undetermined heritage}

The municipality has been very engaged in the design of the new façade and balcony coverings to safeguard the municipal understanding of the qualities and heritage narratives of the existing façades, namely the composition, tactility, colors, what is characterized as a hand-built quality of the original experimental façades as well as the play of shadows produced by the façades when built. This has resulted in the municipal request that the existing concrete cast flower bowls and the original shadow effects should somehow be 
represented in balcony coverings. The solution is a concrete box with no other function than casting a shadow like the original flower bowl. Also, the new glazing, covering the balcony will be slightly recessed from the rest of the façade, and the frames will be painted in a dark color unlike the other new white window frames - all to reinforce the impression of the original façade composition (Fig. 2).

Overall, the new façade is designed to resemble the original one when it comes to composition, color, material, and texture. The main differences being that the buildings are increased in width and depth due to the added insulation and new façade construction. Paramount is also the new structural system of light steel rafters and $45 \times 51 \mathrm{~cm}$ concrete tiles. This system is developed to convey the qualities of the existing concrete façade construction system consisting of prefab, room-size concrete slabs pre-mounted with the original tiles (Fig. 3). The façade slabs with tiles were placed in the construction on site and used as the outer frame for the casting of the inside concrete walls. The new steel construction system is fastened to the original concrete construction, insulation and windstops are added, and the new tiles hung on the steel system of rafters. This solution leads to another notable difference, namely, that the joints between the new concrete tiles will be air, not concrete.
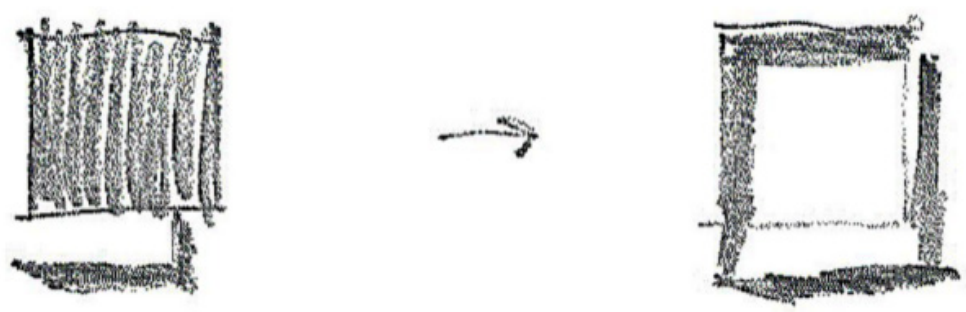

Figure 2: Sketch made by JJW Architects showing the shadow effect of an original, recessed, open balcony with flower bowl and the expected visual effect of the future solution with the slightly recessed glass covering and the new concrete box.
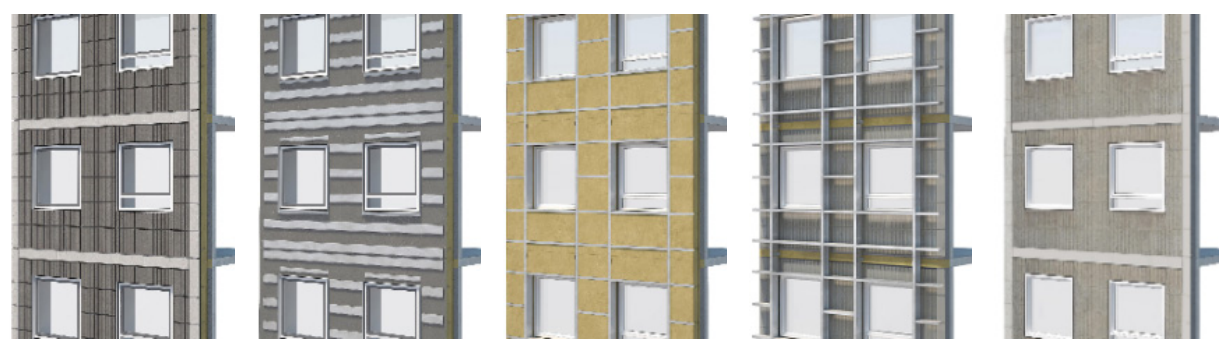

Figure 3: Renderings of the new façade construction. From right to left; original concrete tile façade, new steel rafters attached to the original façade, insulation, windstop and rafters, new concrete tiles. Renderings by JJW Architects. 
The Søndermarken case is to some extent out of the ordinary compared to other Danish public housing renovation projects because of its long duration of almost ten years owed to several changes in project content and budget. Additionally, the new façade construction has been developed from scratch to meet the demands to safeguard, as well as to update, a rare construction type in Danish context. This has complicated the process significantly. The advisors have almost all been replaced due to the long duration of project development, both on the advisor teams, in the municipality and NBF. This has led to questioning of already made decisions due to uncertainty as to why and how decisions were made and with which arguments. Also, the initial budget has proved incapable of adopting price development over time, but more importantly, the original master plan had not been cleared with the municipality as how to deal with preservation issues before applying with the NBF. Neither had the advisors in charge of the initial masterplan or the housing association described their thoughts on heritage consideration - other than the estate had received an architectural award from the municipality and therefore the qualities of the existing architecture should be held in mind when constructing new façades [38]. In short, the understanding of heritage pertaining to the estate had not been thoroughly discussed, described or problematized, and eventual additional costs of construction due to heritage performance were not foreseen when the initial application and budget were sent to, and approved by, the NBF, thus sanctioning the overall economy and project content.

The heritage performativity of the future Søndermarken is now approved by all competent decision-making partners and explained by the approved project description as follows [39]: "The main idea of the façade renovation is to maintain the façades geometry and materiality, not to make an exact copy of the existing façade - the buildings are expanded due to the extra insulation by approximately $33 \mathrm{~cm}$ in all directions - but to preserve the original architectural idea of the façades in the broadest sense". As mentioned above, the municipality finds that the projected solution is in line with the spirit of Søndermarken as the new façade is both prefabricated and has a handbuilt quality. The new small, hand mounted/hung tiles are adaptable to construction deviations in the existing buildings just as the original color tactility and composition is represented in the new façades

\section{DEMOCRATIZING HERITAGE?}

The role of the advisor teams and their attitude towards how to conceive and handle heritage in the project design of Søndermarken has been left out of this paper. However, despite the simplification of the analysis above, The Balcony Controversy can be used to outline some arguments of importance that point towards the gap between theory promoting heritage as a common ground directing change and current practice.

To sum up, the heritage consideration was primarily the concern of the municipality and therefore also brought into the project on the basis of an expert understanding and authorized heritage discourse with two topics of concern: firstly, the municipality saw the original façade composition, materiality, and the open balconies as an aesthetic quality; secondly, according to the municipality, Søndermarken is also of cultural and historical importance as one of the first attempts to industrialize housing construction in Denmark. This view places Søndermarken in a national narrative of housing development and the political, social and architectural ambitions of the 1950s. The municipality made their demands to safeguard their valuation of the heritage narrative of Søndermarken after the NBF application, and the budget was approved by both NBF, the tenants, and the municipal supervisory department. The result was that the heritage agenda was driven forward mainly by the municipality a bit untimely in the project development process and the compromises made regarding heritage conveying 
was often made due to other issues than that of a common heritage understanding and concern. Most notably, the heritage understanding was not a result of a democratic process of valuation.

\subsection{Performing and mediating architectural heritage}

The new façade is carefully designed to represent the valued visual features of the original façade, which will be covered up. One could argue that the original material, traditionally valued within authorized heritage practice is to some extent preserved behind the new one, though not visible. If the new façade were to be removed in the future, the old construction would be there, yet without the parapets and slightly punctured by the new steel anchors. The new façade will according to the renderings and tile samples look quite similar to the original façade in composition, texture, material and color. However, the altered building proportions is a significant change from a traditional architectural point of view, where proportion, composition, construction, materiality, detailing and functionality should be conceived in an interdepending whole when designing a piece of architecture of Alberti's Concinnitas (harmony) or of Vitruvius' Utilitas, Firmitas, and Venustas (utility, solidity, and beauty) [40], [41]. When later altering one of these components, the rounded idea behind the original piece of architecture and its physical appearance will be affected. Another major change is that the concrete joints between the façade tiles will be replaced by air, revealing the new light façade system. This is somewhat askew with the intention of preserving the original architectural effort of prefab concrete housing construction, although one could argue that the development of an entirely new façade construction system is pioneering - as was the original construction. It seems harder to argue for the heritage performance of the new parapets with the non-functional concrete boxes beyond visual representation, simply because they seem to go directly against the idea behind the modernist early-prefab constructions whether one argues for safeguarding the idea behind the original or of conserving the buildings as a historical document [42].

\subsection{Negotiating heritage}

The tenant representation's claim to get rid of the balconies due to functional reasons could have been promoted as a heritage argument by stating that the original intention of the buildings was functional housing, and if the balconies are no longer perceived as a functional quality, demolishing them would be in line with the original idea. In the same way, NBF's claim of the opposite could have been promoted equally by stating that the balcony/bay window element was a significant element in the 1950s model quality housing and therefore should be preserved as a part of the heritage narrative. Instead of debating with temporary tenants over housing quality such an argument would be in line with the authorized heritage discourse promoting buildings as historical documents.

There is no doubt that the architectural interventions chosen to convey the heritage of Søndermarken represent a compromise, they come across as the result of temporary restings of multiple controversies. The façade and balcony solution differ significantly from traditional preservation strategies. The heritage of Søndermarken is mainly conveyed as a visual interpretation of the valued heritage narrative primarily defined by the municipality and authorized heritage management and practice. The important conclusion to draw from Søndermarken and the balcony controversy is thus twofold. Firstly, the heritage consideration was negotiable even though the understanding of heritage promoted was that of the heritage experts and the authorized heritage discourse and practice. Secondly, the negotiations 
between the partners affecting the heritage conveying were not conducted entirely on the basis of heritage concerns. To know whether expressively democratizing heritage understanding and consideration in these projects can work as a progressive common to drive change or not is very much dependent on theory and practice informing each other in a far more productive way through well-described processes and their ability to help qualify common understandings and the performance of interventions. How to decide, for instance, when a national narrative should be prioritized over inhabitants' perception of quality housing and the reinterpretation of the original housing idea in a particular project?

\section{CONCLUSION}

The case study has shown an example of the gap between heritage management and preservation efforts in Søndermarken and the aim of democratizing heritage as common ground from which to direct changes. The negotiation of how to convey Søndermarken's heritage was made primarily on the basis of the authorized heritage discourse represented by the municipality. Heritage concern was not established as a common ground at the beginning of the project development process from which change and intervention were discussed. If we indeed should seek to democratize valuation and managing of built heritage further as promoted with New Heritage, scrutinizing how negotiations can be made on common grounds in order to make claims heard despite the inevitable unequal power-relations within projects is central.

Research into heritage conveying processes are needed, not only to better understand varying ways of conveying heritage in the built environment, but also to qualify the process of negotiation of heritage interpretation and assessment itself. But more importantly, we are also in need of strategies to critically evaluate and prioritize such claims since heritage certainly implies valuation whenever it is deployed actively, the valuation of someone but not all. A critical matter in a still functioning public housing sector where temporary tenants are expected to safeguard an acclaimed national built heritage.

Therefore, we need to be even more particular on the negotiation process of reaching this common ground, exploring the when and why to value heritage aspects. Only then, can we ensure the conditions to unfold the potentials of such heritage negotiation, in turn enabling us to qualify how to convey our reached common ground successfully through architectural interventions. It cannot merely be boiled down to a discussion of whether to safeguard and promote an existing "idea or image". It is considerably more complex than that; a complexity clearly showcased when dealing with still functioning housing as in the public housing sector. When to prioritize original material, for instance, an original façade, over current functional requirements such as insulation and energy policies? When do we decide that the original idea of high-quality housing such as apartments with balconies should be conveyed by altering the original plans to modern living models and thus erasing the past version of these? To think of heritage discussions as a common ground from which we can direct changes in the built environment requires strategies on how to make these decisions, as democracy does not necessarily ensure the best decisions. Fink argues that value assessment can be objective and that some things objectively can be assessed better than something else. However, in this context, the premise to do so is that the heritage notion in question becomes clearly established in each project. Moreover, for the process to reach this kind of agreement, it must be well recognized to ensure it is successful in serving as the fundament of this objective assessment. Only when this process is established can we decide which understanding of heritage we are safeguarding in the particular project and seek to qualify how to convey these heritage notions through new architectural interventions in practice and in return feed back into theory. 


\section{REFERENCES}

[1] Fairclough, G., New heritage frontiers. Heritage and Beyond, Council of Europe: Strasbourg, p. 30, 2009.

[2] Harrison, R., Beyond 'natural' and 'cultural' heritage: Toward an ontological politics of heritage in the age of Anthropocene. Heritage \& Society, 8(1), pp. 24-42, 2015. DOI: 10.1179/2159032X15Z.00000000036.

[3] Bech-Nielsen, G., Restaurering versus instaurering og transstaurering: $P h D$ afhandling om holdningen som arkitektfagligt instrument, $\mathrm{PhD}$ thesis, Aarhus, p. 235, 2012 [in Danish].

[4] Stenbro, R., Bevaringsprocesser: Perspektiver på arkitektur i forandring, $\mathrm{PhD}$ thesis, Aarhus, pp. 99-100, 2009 [in Danish].

[5] Fairclough, G., New heritage frontiers. Heritage and Beyond, Council of Europe: Strasbourg, pp. 29-42, 2009.

[6] Smith, L., Uses of Heritage, Routledge: London, p. 11, 2009.

[7] Harrison, R., Beyond 'natural' and 'cultural' heritage: Toward an ontological politics of heritage in the age of Anthropocene. Heritage \& Society, 8(1), pp. 24-42, 2015. DOI: $10.1179 / 2159032 X 15 Z .00000000036$.

[8] Arkitema Architects (ed.), Nye Udfordringer for det Almene Boligbyggeri, Landsbyggefonden, p. 11, 2014.

[9] Bech-Danielsen, C., Jensen, J.O., Kirkeby, I.M., Ginnerup, S. Clementsen, A. \& Hansen, M.Ø., Renovering af Efterkrigstidens Almene Bebyggelser: Evaluering af ti Renoveringer med Fokus på Arkitektur, Kulturarv, Bæredygtighed og Tilgæengelighed, Statens Byggeforskningsinstitut: Hørsholm, 2011.

[10] Bech-Danielsen, C., Bøgh, S. \& Østergaard, J., Kvaliteter i Almene Bebyggelser fra 1940'erne og 1950'erne, Bygningskultur Danmark: Copenhagen, 2013.

[11] Tietjen, A. (ed.), Forstadens Bygningskultur 1945-1989: På Sporet af Velfcerdsforstadens Bevaringsvcerdier, Dansk Bygningsarv: Copenhagen, 2010.

[12] Dansk Bygningsarv, Morgen, M.A. \& Bendsen, J.R. (eds), 1940'ernes og 50'ernes Murede Boligbebyggelser: Bygningskultur og Bevaringsverdier, Kulturstyrelsen, Realdania, Landsbyggefonden \& Grundejernes Investeringsfond: Copenhagen, 2015.

[13] Hangaard, T., Jensen, A., Trampe, T., Hansen, O.K. \& Reinhold, P., Arven fra 1950erne. Den Almene Sektors Bygningskultur, AlmenNet, 2011.

[14] Landsbyggefonden, Beboere i den Almene Boligsektor 2015, Landsbyggefonden: Copenhagen, 2015.

[15] Dansk Bygningsarv (ed.), 1940'ernes og 1950'ernes Murede Boligbebyggelser: Kom godt $i$ gang med at Renovere, Kulturstyrelsen, Realdania, Landsbyggefonden \& Grundejernes Investeringsfond: Copenhagen, 2015.

[16] Observation of meetings between NBF, municipalities and housing associations applying for renovation funding, April 2015.

[17] Sehested, K., Planlægning og styring i den grænseløse by. Den grcenseløse by, Center for Strategisk Byforskning, p. 121, 2013.

[18] Smith, L., Uses of Heritage, Routledge: London, p. 299, 2009.

[19] Stenak, M. (ed.), SAVE - Kortlcegning og Registrering af Bymiljøers og Bygningers Bevaringsvcerdi, Kulturarvsstyrelsen: Copenhagen, 2011.

[20] Kulturstyrelsen, Bevaringsprincipper, Kulturstyrelsen: Copenhagen, 2012/2015.

[21] Koziol, C., How heritage's debate on values fuels its valorization engine: The side effects of controversy from Alois Riegl to Richard Moe. Change Over Time, 3(2), pp. 244-257, 2013. DOI: 10.1353/cot.2013.0012. 
[22] Fojut, N., The philosophical, political and pragmatic roots of the convention. Heritage and Beyond, Council of Europe: Strasbourg, pp. 13-22, 2009.

[23] Fairclough, G., New heritage frontiers. Heritage and Beyond, Council of Europe: Strasbourg, pp. 29-42, 2009.

[24] Harrison, R., Beyond 'natural' and 'cultural' heritage: Toward an ontological politics of heritage in the age of Anthropocene. Heritage \& Society, 8(1), pp. 24-42, 2015. DOI: $10.1179 / 2159032 X 15 Z .00000000036$.

[25] Sieverts, T., Counteracting acceleration and abstraction, fostering emotion and handling uncertainties by experiments. The principle of heritage-preservations and its generalization in the Anthropocene. Urbanism in the Anthropocene Seminar, Aarhus, Denmark, p. 7, 2016.

[26] Bech-Nielsen, G., Restaurering versus instaurering og transstaurering: Ph.D.afhandling om holdningen som arkitektfagligt instrument, $\mathrm{PhD}$ thesis, Aarhus, pp. 5462, 2012 [in Danish].

[27] Kulturarvsstyrelsen, SAVE-Kortlægning og registrering af bymiljøers og bygningers bevaringsvcerdi, Kulturarvsstyrelsen: Copenhagen, 2011.

[28] Kulturarvsstyrelsen, Vejledning. Vurdering af Fredningsvæerdier, Kulturarvsstyrelsen: Copenhagen, undated.

[29] Kulturministeriet, Bekendtgørelse af Lov om Bygningsfredning og Bevaring af Bygninger og Bymiljøer, LBK nr 970 af 28/08/2014, 2016.

[30] Bech-Nielsen, G., Restaurering versus instaurering og transstaurering: $\mathrm{PhD}$ afhandling om holdningen som arkitektfagligt instrument, $\mathrm{PhD}$ thesis, Aarhus, p. 230, 2012 [in Danish].

[31] Yaneva, A., Mapping Controversies in Architecture, Ashgate Pub. Co.: Burlington, 2011.

[32] Venturini, T., Diving in magma: How to explore controversies with actor-network theory. Public understanding of science, 19(3), pp. 258-273, 2010.

[33] Stenbro, R., Bevaringsprocesser: perspektiver på arkitektur i forandring, $\mathrm{PhD}$ thesis, Aarhus, 2009 [in Danish].

[34] Overgaard, S. M., Verdiforskydninger i arkitektonisk kulturarv: Herregårdenes avlsbygninger - udviklingsbetingede ombygninger og arkitektoniske kulturarvsvcerdier, $\mathrm{PhD}$ thesis, Aarhus, 2013 [in Danish].

[35] Fink, H., Elementer af en almen værditeori - med et vist henblik på æstetik og kulturpolitisk evaluering. Kunstnerisk kvalitet i kulturpolitikken, Kommunes Fritidsog Kulturforvaltning: Aarhus, p. 20, 2002.

[36] Landsbyggefonden, Vejledning om Støtte fra Landsbyggefonden til Opretning, Udbedring, Vedligeholdelse, Forbedring, Ombygning, Sammenlcegning af Lejligheder og Miljøforbedring i Alment Byggeri samt om Tilskud til Infrastrukturcendringer i Udsatte Almene Boligområder, Landsbyggefonden: Copenhagen, 2015.

[37] Employee, Frederiksberg Municipality, 2 Sep. 2016.

[38] Frederiksberg Municipality, Helhedsplan FFB, AFD. Søndermarken, Godkendelse af Skema A, 2011.

[39] JJW Arkitekter, Søndermarken. Projektforslag IV - Beskrivelse, 2016.

[40] Vitruvius, P., VITRUV: Om Arkitektur, University Press Southern Denmark: Odense, p. 21, 2016.

[41] Nygaard, E., Arkitektonisk kvalitet: et forsøg på en kortfattet definition. NA, 15(1), pp. 91-96, 2015.

[42] Heynen, H., Questioning authenticity. National Identities, 8(3), pp. 287-300, 2006. 